\title{
Does Capital Gains Tax Add to or Detract FROM The FAIRness OF The SOUTH African TAX System?
}

\author{
Warren Maroun, Magda Turner and Kurt Sartorius \\ School of Accountancy, University of the Witwatersrand
}

Accepted: July 2011

\begin{abstract}
This research adds to the existing body of knowledge on the perceived impact of capital gains tax (CGT) on the fairness of the South Africa tax system. Building on the largely qualitative work done by Vivian (2006) and Smith (1776), the research makes use of an extensive literature review followed by a correspondence analysis to complement the existing body of research in this area. The literature review discusses the fairness criteria advanced by Smith (1776) (Smith's tax canon) and the identified 'unfairness characteristics' of CGT. The correspondence analysis only tests the theories advanced in the literature review and reveals that there are potential sources of unfairness inherent in the Eighth Schedule to the Income Tax Act No. 58 of 1962 (the Eighth Schedule). These include the possibility that CGT gives rise to double tax and imposes a high burden on taxpayers' ability to bear the tax load. The findings are relevant in practical terms in that they may have policy implications for subsequent revisions to the Eight Schedule. Theoretical contributions are made by exploring the perceived fairness of CGT using the theory of tax fairness advanced by Smith (1776).
\end{abstract}

Key words: fairness, inflation, 'bunching', lock-in, equity, correspondence analysis

JEL: E30, $\mathrm{H} 20$

\section{1}

\section{Introduction}

The introduction of CGT has been cited as a key source of unfairness in the South African tax system. In particular, the tax has been denounced as a tool of political expediency, as well as a destroyer of initiatives because it places an undue burden on taxpayers. CGT has also been cited as an attack on the capital base of South Africa's economic reform and growth (Voster, 2000; Meyerowitz, Emsile \& Davis, 2001a; Conda, 2006; Dyl, 1977; Roberts, 2006; Stein 2000). Smith's (1776:V.II.II) first canon of taxation suggests that four attributes can contribute to an unfair tax system: firstly, if the 'seed' of a taxpayer's income is taxed, in addition to the "fruits", a tax is being levied on both income and capital, resulting in double tax and an erosion of a taxpayer's ability to generate taxable income (Vivian, 2006:83). Secondly, only amounts earned under the protection of the state should be taxed (Vivian, 2006:84) implying that a source-based system of taxation is superior to the current residencebased system. Thirdly, a taxpayer needs to have the ability to bear a tax's burden and not merely the ability to pay it (Smith 1776; Vivian, 2006:84). A balance is necessary between the state's inexorable pursuit of revenue and the citizen's right to survive (Vivian, 2006:84-85 \& Montesquieu, 1748: XIII.1). Finally, a progressive system of tax may be less desirable than a proportional one (Vivian, 2006).

Despite a considerable body of literature on CGT from a positive economic and technical perspective, scant research has been done on the perceived fairness of CGT. What little has been written has tended to be informal, lacking in empirical analysis and not rooted in a theoretical approach. Little effort has been made to elicit the opinions of CGT practitioners or to contrast emerging perceptions from multiple sources and to consider the relevance of economic theories such as Smith's (1776) theory of tax fairness. 
The objective of this paper is to explore the perceived 'fairness' of CGT, in order to contribute to a better understanding of the impact of CGT, as well as to configure the Eighth Schedule and the fairness criteria advanced by the tax canons of Smith (1776). Using a detailed analysis of the relevant literature, coupled with a correspondence analysis, based on the perceptions of a sample of tax experts, the paper will investigate the fairness of CGT in relation to several concerns. First is the issue of taxation of capital and absence of inflation adjustment. Secondly, whether CGT exacerbates the problem of taxing capital gains at an artificially high rate by virtue of the sliding tax scales (the 'bunching problem') and artificially discouraging realisation of capital gains (lock-in problem). Third, whether CGT is inconsistent with the notion of concentrating the tax burden on the rich and taxing taxpayers in similar economic conditions equally (vertical and horizontal equity respectively). Finally, the paper will question whether CGT promotes anti-avoidance behaviour (structuring of transactions with an aim of avoiding a CGT charge) and whether the burden of administering this tax is cost effective.

An outline of the remainder of the paper is structured as follows: Section 2 discusses unfairness criteria with a view to the development of a questionnaire for tax experts. Section 3 outlines the data and method used to test the research questions. Section 4 develops the results, as well as a series of discussions. Finally, Section 5 concludes the study and makes some recommendations.

\section{2}

\section{The unfairness of capital gains tax (CGT)}

The unfairness of CGT was evaluated from a double tax perspective, from the 'bunching' or lock-in effect, whether it affected vertical and horizontal equity and whether inflation contributed to the unfairness of this tax. Finally, CGT is discussed with respect to its impact on tax avoidance, as well as the cost of its administration.

\subsection{Double tax}

The fruits of the taxpayer's efforts may be taxed but not the seed of those fruits (Smith, 1776). In other words, the 'fruits' or income of the taxpayer may be taxed but not the 'seed', 'tree' or capital receipts of the taxpayer (Stiglingh, Koekemoer \& Wilcock, 2011; Vivian, 2006). A failure to comply carries two interrelated disadvantages: firstly, the tax may erode the assets used to generate income and pay taxes; secondly, the effect of taxing capital may be a double tax (Vivian, 2006:83; Ricardo, 1817). The result is economic ruin: the ability of a taxpayer to bear the tax burden is impaired, as are the funds used to maintain labour and generate wealth (Ricardo, 1817:63). Empirical evidence would suggest countries adopting CGT generally reported lower per capita income due to capital erosion (Dyl, 1977; Stein, 2000; Stein, 2001; PwC, 2000). This evidence would support Ricardo's (1817) contention which regards capital as 'the seed corn of the nation from which income is earned' and a part of the foundation of a taxpayer's ability to generate income. When 'capital is [reduced a taxpayer's] economic foundation and his ability to generate income is diminished' (Stein, 2000:12).

The taxation of inheritances may result in a similar problem (Smith, 1776; Ricardo, 1817). In this context, the provisions of para 40 of the Eighth Schedule that deals with the CGT of any disposal to or from a deceased estate may be relevant. Upon death, a deceased person is deemed to have disposed of his or her assets for an amount equal to the market value of those assets at the date of the person's death and such deemed disposal is subject to taxation in the form of CGT (Para $20 \& 40$ of the Eighth Schedule). This may force the deceased estate to realise certain assets to settle the CGT charge and detract from the recipient's inheritance (Stiglingh et al. 2011:855; Moore \& Silva: 1995:87). In this way, a form of double tax arises which impairs the capital base of the nation (Ricardo, 1817). Capital gains are also the product of improvements in respective companies' post-tax cash flows rendering CGT as a form of double tax. Stein G (2001) negates the South African 
Revenue Service's (SARS) view that CGT is a fair charge on wealth realization by implying that CGT is a further tax on the selling prices of shares that already reflect the accumulated profits of a company. (Stein, 2000:102).

\subsection{The 'bunching' and lock-in problem}

Second, only amounts earned under the protection of the state should be taxed (Vivian, 2006: 84). This could imply that a sourcebased system of taxation is superior to the current residence-based system. Smith (1776) requires a tax to allow for only a fair remuneration for state-sponsored services with a tax representing only a fair quid pro quo (Vivian, 2006:82-83). Per Conda (2006), however, CGT has resulted in a 'locking in' of capital gains. Simply, CGT may 'lock-in' or discourage the realization of capital assets at the most efficient times. The result: assets may not be disposed of at the most efficient times or to the most effective users. The lock-in effect frustrates tax collection and the state's capacity to execute social-upliftment projects to the detriment of the poor (Conda, 2006). Secondly, the lock-in could result in a lower CGT rate stimulating realizations and improve state revenue (Auten \& Cordes, 1991). Paradoxically, it may be possible to generate higher revenue, and offer improved state services, with a lower CGT rate (Dyl, 1977; Moore \& Kerepen, 2001:5-6; Leonard, Randolph B \& Randolph W, 2002; Roberts, 2006:1). This potential is magnified when one considers that relief offered under the rating formula is not available to minimise the negative impact of an excessively high CGT rate.

Nonetheless, these findings have been refuted by Brooks (2001) and SARS (2010; 2000) who assert that the conclusions are idealistic in that they rely on the assumption of perfect market efficiency to direct capital resources with optimal efficiency. In contrast, the absence of CGT would arguably lead to investment decisions motivated by tax avoidance rather than maximisation of society's utility. Indeed, such selfishness would necessitate a compensatory tax rate increase (SARS, 2010; Brooks, 2001:2; SARS, 2000). There is no guarantee that market forces alone will produce a socially fair result (SARS, 2000; Congress of South African Trade Unions (COSATU), 2001).

\subsection{Vertical and horizontal equity}

Third, the taxpayer needs to have the ability to bear a tax's burden and not merely the ability to pay it (Smith, 1776; Vivian, 2006:84). A balance is necessary between the state's 'inexorable' pursuit of revenue and the citizen's right to survive (Vivian, 2006:84-85; Montesquieu, 1748:XIII.1). In other words, equity theory is relevant. Taxpayers in equal positions should have equal tax commitments (horizontal equity) while wealthier taxpayers ought to shoulder a larger tax load (vertical equity) (Farrar, 2011; Vivian, 2006). The Katz Commission (1997) and Institute for Fiscal Studies in England (1978) maintained that CGT is instrumental in entrenching the ideals of horizontal and vertical equity in the tax system.

Equity has been achieved by ensuring that vast amounts of capital are not left untaxed in the hands of a wealthy minority and by taking cognizance of the need for the wealthy to spare the poor an undue tax burden (Katz Commission, 1997:46; Meade, 1978:12; Stiglitz, 1976; SARS, 2000). The need to remedy the legacy of Apartheid has made these views particularly valid (COSATU, 2001; Ensor (e), 2001:11). In this context, the Carter Commission (1966), Musgrave (1968) and SARS (2000) endorse CGT as being aligned with the notion of allowing taxpayers to bear the tax load in proportion to their ability to do so.

It has, however, been argued that vertical equity penalises the economically efficient to the detriment of the tax base. Mandatory charity may also be counter philanthropic (Coetzee, 1998:5; Voster, 2000; Farrar, 2011). CGT's ability to redistribute wealth and achieve vertical equity becomes tantamount to the state '[turning] the strong into the weak; the healthy into the sick and the wise into the stupid to make them equal' (Voster, 2000: 125). The lock-in effect aggravates the situation by paradoxically forcing the lower income worker who is forced to sell off an inheritance due to an inability, not experienced 
by the wealthy, to defer a capital gain (Groves \& Curran, 1974; Voster, 2000; Moore \& Kerpen, 2001; Moore \& Silva, 1995). In this way, equity may be dismissed as lacking pragmatism. Indeed, the quantification of households' abilities to pay taxes may be too difficult to be a feasible justification for CGT (Coetzee, 1998:10-12).

\subsection{Issue of inflation adjustments}

The absence of inflation adjustment serves only to aggravate the 'bunching' and lock-in problem (Staszczuk, 2001:10; Cordes, 2000:3). While inflation indexing may be possible, it could prove 'horribly administratively complex' and too costly a solution (Croome, 2007; Olivier, 2007; Krever, 2001). Indeed most OECD countries made no provision for inflation adjustment in CGT calculations, except under hyperinflationary conditions (Ensor, 2000:1). The fact that the exemptions and exclusions are in place and that inflation impacts on all aspect of life may suggest that detailed inflation adjustments are not required (Krever, 2001; Ensor, 2000:1).

\subsection{The anti-avoidance potential and administrative requirements}

CGT's potential to discourage the concealment of wealth realization as capital gains has been part of the arguments in favour of CGT in several countries (Moore \& Silva, 1995; Wood, 2001:13; Cameron, 2001). SARS maintains that CGT 'protects the integrity of ... the tax base and...materially assists in improving tax morality' (SARS, 2000). By protecting the tax base, it is also argued that this may lead to the future alleviation of the burden created by other taxes (SARS, 2010; Friedland, 2001; Wood, 2001:113.).

Critics, however, challenged CGT's antiavoidance potential. Paradoxically, in the context of globalisation, tightening the tax net has led to ever more creative tax avoidance schemes (Thomas, 2001:17; Honiball: 2007, pers. comm., 16 November). This shortcoming is complemented by CGT's alleged complexity (Croome, 2007; Olivier, 2007) and administration burden such as the need for complex pre 1 October 2001 valuations and maintenance of detailed schedules in support of capital gains and losses (Wood, 2001:114; Meyerowitz et al. (b,c \& d), 2001:82).

\section{3}

\section{Data and method}

This paper adopted an inductive approach to explore the fairness criteria of CGT. A survey questionnaire was developed on the basis of a literature review, as well as the opinions of a sample of tax academics and tax practitioners. The reliability of the questions was then subject to a number of pilot tests (Leedy \& Ormrod, 2001) and further amendments made or additional questions added. In essence, the population surveyed consisted of registered taxpayers with an understanding of the Eighth Schedule. A purposeful selection technique was applied to this population with a view to selecting only tax experts (tax partners) from several audit firms, SARS officials and academics specialising in tax. A sample size of 60 experts was, therefore, relied upon (Creswell, 2009) because of a limitation of tax experts.

Purposeful selection using small sample sizes enhances the quality of the research findings by ensuring that only participants knowledgeable of the Eighth Schedule are engaged (Creswell, 2009; Brennan \& Kelly, 2007; Blaxter, Hughes and Tight, 2003). Further, the research takes on an interpretive style. The aim is to shed light on the perceived fairness of CGT from the perspectives of informed practitioners. As such, the study is grounded in a social constructivist outlook (Creswell, 2009). The intention is neither to 'quantify tax fairness' nor to generalise the findings. In a similar ontologically inspired study, O'Dwyer, Owen and Unerman (2011), for example, employ purposeful selection techniques using detailed interviews to successfully explore the perceptions of informed participants on auditor legitimisation strategies.

Statistical modelling and testing of hypotheses are dispensed with. Tax 'fairness', by its very nature is subjective making a predominantly positive research approach inappropriate. Validity and reliability of the findings no longer refer to the scope of the results and statistical precision but to the 
depiction of perceptions in a clear and concise fashion (Creswell, 2009; Ahrens \& Chapman, 2006; Neuendorf, 2002:114-115; Parker \& Roffey, 1997).

As a result, the research method is a correspondence analysis. It captures a range of perceptions from relatively small sample sizes (Bendixen, 1996), aggregating the data and presenting it in a simple form. It is well suited for exploratory research, overcoming the potential risk of more interpretive inspired research becoming cumbersome (Creswell, 2009; Bendixen, 1996). As a final check, the choice and use of the correspondence analysis was reviewed by an independent statistician who confirmed the appropriateness of the chosen method and its application.

The survey questionnaire is presented below:

Table 1

Survey Questionnaire

\begin{tabular}{|c|c|c|c|c|c|}
\hline & \multirow[t]{3}{*}{ Statement } & \multicolumn{4}{|c|}{ Absence of fairness criteria } \\
\hline & & \multicolumn{3}{|c|}{$\begin{array}{l}\text { Based on Smith's (1776) definition of a fair tax } \\
\text { system }\end{array}$} & \multirow{2}{*}{$\begin{array}{l}\text { Based on the } \\
\text { South African } \\
\text { context } \\
\text { Does not } \\
\text { promote the } \\
\text { upliftment of } \\
\text { the disadvan- } \\
\text { taged }\end{array}$} \\
\hline & & $\begin{array}{l}\text { Gives rise to } \\
\text { double tax } \\
\text { as CGT is a } \\
\text { tax on } \\
\text { capital }\end{array}$ & $\begin{array}{l}\text { Does not ensure } \\
\text { that all taxpayers } \\
\text { contribute fairly for } \\
\text { state-provided } \\
\text { services. }\end{array}$ & $\begin{array}{l}\text { Undermines } \\
\text { ability to } \\
\text { support the } \\
\text { taxpayer's } \\
\text { family }\end{array}$ & \\
\hline 1 & $\begin{array}{l}\text { The sale of an equity instrument which is capital in nature } \\
\text { is subject to CGT (para 2). }\end{array}$ & & & & \\
\hline 2 & Capital losses are ring- fenced (para 7 to para 9). & & & & \\
\hline 3 & $\begin{array}{l}\text { On death, a taxpayer suffers a deemed disposal reducing } \\
\text { the heir's inheritance (para 40). }\end{array}$ & & & & \\
\hline 4 & $\begin{array}{l}\text { CGT discourages capital gain realisations as CGT } \\
\text { normally arises only on a disposal of the respective asset. }\end{array}$ & & & & \\
\hline 5 & $\begin{array}{l}\text { CGT encourages capital loss realisations as the capital } \\
\text { loss is then available for set-off against capital gains } \\
\text { resulting during the tax year. }\end{array}$ & & & & \\
\hline 6 & $\begin{array}{l}\text { CGT prevents domestic revenue being converted into tax } \\
\text { free capital gains. }\end{array}$ & & & & \\
\hline 7 & $\begin{array}{l}\text { CGT prevents foreign revenue being converted into tax } \\
\text { free capital gains. }\end{array}$ & & & & \\
\hline 8 & $\begin{array}{l}\text { CGT requires detailed supporting documentation (part I } \\
\text { and II of the Act). }\end{array}$ & & & & \\
\hline 9 & $\begin{array}{l}\text { Steps to simplify administrative requirements for CGT } \\
\text { have been taken. }\end{array}$ & & & & \\
\hline 10 & CGT taxes the wealthy. & & & & \\
\hline 11 & $\begin{array}{l}\text { CGT promotes the equal taxing of taxpayers in equivalent } \\
\text { economic positions. }\end{array}$ & & & & \\
\hline 12 & $\begin{array}{l}\text { Inclusions under s } 26 \mathrm{~A} \text { of the Act are not subject to s } \\
7 \mathrm{~A}(4 \mathrm{~A}) \text { of the Act. }\end{array}$ & & & & \\
\hline 13 & $\begin{array}{l}\text { There is no direct inflation adjustment in the Eighth } \\
\text { Schedule. }\end{array}$ & & & & \\
\hline 14 & PBOs are not subject to full CGT exemption. & & & & \\
\hline 15 & Recreational clubs are not subject to full CGT exemption. & & & & \\
\hline 16 & $\begin{array}{l}\text { The CGT effects of s } 41 \text { to s } 47 \text { pose difficulties for BEE } \\
\text { deals. }\end{array}$ & & & & \\
\hline 17 & CGT acts as a disincentive to business start-ups. & & & & \\
\hline 18 & $\begin{array}{l}\text { Small business exemptions (para } 57 \text { ) and deductibility of } \\
\text { capital losses from capital gains (para } 7 \text { ) are possible. }\end{array}$ & & & & \\
\hline 19 & $\begin{array}{l}\text { The new three year rule (relating to the minimum period } \\
\text { shares need to be held in order to constitute a capital } \\
\text { disposal) discourages speculative investing }\end{array}$ & & & & \\
\hline 20 & CGT in general & & & & \\
\hline
\end{tabular}


Respondents were required to mark with an ' $\mathrm{X}$ ' those statements that corresponded with 'absence of fairness criteria'. Individual sheets were aggregated. A final 18 row x 4 column contingency table captured the total responses. Each response (' $\mathrm{X}$ ') was allocated a numerical value of one. A non-response (blank cell) was allocated a value of zero. The data were analysed, using correspondence analysis that incorporated a two-dimensional graphical plot (Bendixen, 1996) of the opinions of tax experts with respect to the fairness of the 18 paragraphs of the Eighth Schedule. The analysis was completed using STATA and was subject to independent review. The descriptive statistics report is provided below:

Table 2

Descriptive statistics

\begin{tabular}{|l|llr|}
\hline & Number of obs & $=$ & 1053 \\
\hline & Pearson chi2(57) & $=$ & 266.97 \\
\hline & Prob $>$ chi2 & $=$ & 0.0000 \\
\hline & Total inertia & $=$ & 0.2535 \\
\hline 20 active rows & Number of dim. & $=$ & 2 \\
\hline 4 active columns & Expl. inertia $(\%)$ & $=$ & 90.22 \\
\hline
\end{tabular}

\begin{tabular}{|l|c|c|c|c|c|}
\hline \multicolumn{1}{|c|}{ Dimension } & Singular principle value & inertia & chi $^{\mathbf{2}}$ & per cent & Cumul per cent \\
\hline $\operatorname{dim} 1$ & .3607797 & .130162 & 137.06 & 51.34 & 51.34 \\
\hline $\operatorname{dim} 2$ & .3139545 & .0985674 & 103.79 & 38.88 & 90.22 \\
\hline $\operatorname{dim} 3$ & .157489 & .0248028 & 26.12 & 9.78 & 100.00 \\
\hline total & \multicolumn{2}{|c|}{$\mid 2535322$} & 266.97 & 100.00 & \\
\hline
\end{tabular}

Statistics for row and column categories in symmetric normalisation

\begin{tabular}{|c|c|c|c|c|c|c|c|c|c|}
\hline \multirow{2}{*}{$\begin{array}{c}\text { Rows } \\
\text { categories }\end{array}$} & \multirow{2}{*}{ Mass } & \multirow{2}{*}{ Quality } & \multirow{2}{*}{ \%inert } & \multicolumn{3}{|c|}{ Dimension 1} & \multicolumn{3}{|c|}{ Dimension 2} \\
\hline & & & & coord & sqcorr & contrib & coord & sqcorr & contrib \\
\hline s1 & 0.086 & 1.000 & 0.098 & 0.812 & 0.824 & 0.158 & 0.402 & 0.175 & 0.044 \\
\hline s2 & 0.031 & 0.818 & 0.015 & -0.502 & 0.766 & 0.022 & 0.140 & 0.052 & 0.002 \\
\hline s3 & 0.112 & 0.995 & 0.042 & 0.321 & 0.394 & 0.032 & 0.424 & 0.601 & 0.064 \\
\hline s4 & 0.060 & 0.961 & 0.193 & -1.473 & 0.957 & 0.360 & -0.099 & 0.004 & 0.002 \\
\hline s5 & 0.035 & 0.963 & 0.037 & -0.812 & 0.897 & 0.064 & -0.235 & 0.065 & 0.006 \\
\hline s6 & 0.028 & 0.719 & 0.035 & -0.661 & 0.501 & 0.035 & -0.467 & 0.218 & 0.020 \\
\hline s7 & 0.028 & 0.809 & 0.040 & -0.832 & 0.671 & 0.053 & -0.405 & 0.138 & 0.014 \\
\hline s8 & 0.076 & 1.000 & 0.041 & -0.173 & 0.078 & 0.006 & 0.638 & 0.922 & 0.098 \\
\hline s9 & 0.047 & 0.994 & 0.050 & 0.303 & 0.124 & 0.012 & 0.863 & 0.871 & 0.113 \\
\hline$s 10$ & 0.023 & 0.315 & 0.027 & -0.431 & 0.224 & 0.012 & -0.295 & 0.091 & 0.006 \\
\hline s11 & 0.030 & 0.793 & 0.004 & 0.190 & 0.360 & 0.003 & -0.224 & 0.433 & 0.005 \\
\hline s12 & 0.036 & 0.965 & 0.023 & -0.569 & 0.739 & 0.032 & -0.338 & 0.226 & 0.013 \\
\hline $\mathrm{s} 13$ & 0.028 & 0.191 & 0.022 & -0.252 & 0.116 & 0.005 & 0.217 & 0.075 & 0.004 \\
\hline s14 & 0.053 & 0.895 & 0.068 & 0.561 & 0.351 & 0.046 & -0.749 & 0.544 & 0.095 \\
\hline s15 & 0.054 & 0.937 & 0.126 & 0.698 & 0.297 & 0.073 & -1.097 & 0.640 & 0.208 \\
\hline s16 & 0.052 & 0.955 & 0.066 & 0.768 & 0.665 & 0.085 & -0.543 & 0.289 & 0.049 \\
\hline s17 & 0.071 & 0.888 & 0.040 & -0.065 & 0.011 & 0.001 & -0.629 & 0.878 & 0.090 \\
\hline s18 & 0.026 & 0.893 & 0.013 & 0.013 & 0.000 & 0.000 & -0.609 & 0.893 & 0.030 \\
\hline s19 & 0.051 & 0.652 & 0.017 & -0.037 & 0.006 & 0.000 & 0.418 & 0.646 & 0.029 \\
\hline s20 & 0.070 & 0.998 & 0.042 & -0.042 & 0.004 & 0.000 & 0.692 & 0.994 & 0.107 \\
\hline
\end{tabular}




\begin{tabular}{|l|l|l|l|l|l|l|l|c|c|}
\hline \multirow{2}{*}{ Columns } & \multirow{2}{*}{ Mass } & \multirow{2}{*}{ Quality } & \multirow{2}{*}{ \%inert } & \multicolumn{3}{|c|}{ Dimension 1 } & \multicolumn{3}{c|}{ Dimension 2 } \\
\hline & & & & coord & sqcorr & contrib & coord & sqcorr & contrib \\
\hline unfair1 & 0.157 & 0.994 & 0.336 & 0.505 & 0.170 & 0.111 & 1.194 & 0.824 & 0.712 \\
\hline unfair2 & 0.249 & 0.981 & 0.356 & -0.992 & 0.978 & 0.679 & 0.052 & 0.002 & 0.002 \\
\hline unfair3 & 0.292 & 0.112 & 0.076 & 0.060 & 0.020 & 0.003 & -0.139 & 0.092 & 0.018 \\
\hline unfair4 & 0.302 & 0.906 & 0.232 & 0.497 & 0.458 & 0.207 & -0.528 & 0.448 & 0.268 \\
\hline
\end{tabular}

In this regard, the row profiles and masses were used to calculate the inertia (variance) attributable to each match (cell) in the contingency table. The coordinates of the Points-rows and Points-columns, as well as the selection of axes (dimensions), illustrated in Figure 1, were developed by principal component analysis (Bendixen, 1996:15-21). The bi-plot details section (Table 2), was then used to define the respective axes illustrated in Figure 1. In this regard, the respective axes based on the four unfairness criteria were determined by the coordinates of each unfairness criteria, the respective inertia of the unfairness criteria and their correlation coefficients with the chosen axis. Unfairness criteria 3 had both a very low level of inertia and weak correlation with two axes.

Figure 1

Axes and labels

\begin{tabular}{ll}
\multicolumn{1}{c}{ Axis } & \multicolumn{1}{c}{ Label } \\
\hline Positive $x$-axis (axis 1) & Unfair 2: Unequal contribution for state-provided services \\
Negative $x$-axis (axis 1) & Unfair 1: Double tax \\
Positive $y$-axis (axis 2) & Unfair 4: Does not promote upliftment \\
\hline Negative $y$-axis (axis 2) & \\
\hline
\end{tabular}

(Adapted from Stacey, 2007, pers. comm., 28 November)

A correspondence plot was then developed to position each of the 18 paragraphs with respect to the four unfairness criteria in a twodimensional graph in order to graphically illustrate any associations among each of the 18 paragraphs and the four unfairness criteria. In this graphical presentation, the further a given point (plotted statement 1-18) was away from the origin (the greater its Chi-Square value-variance), the more it was associated with influencing one or more of the unfairness criteria. This influence is measured as contribution or inertia where the sum of the contributions is referred to as the quality of the plotted point (statement). It should be noted that the sign of a paragraph is only indicative of its positioning relative to other paragraphs. To facilitate easier interpretation, paragraphs with very low inertia are not separately considered. Such simplifications only resulted in a 10 per cent loss of richness given the total inertia considered by the traits above.

\section{4}

\section{Results}

This section presents the findings with respect to the question of whether the paragraphs (statements) of the Eighth Schedule have contributed to four unfairness criteria. In order to do this, a correspondence bi-plot, illustrated in Figure 2, has been developed to show the relationships between various statements in the Eighth Schedule and the four unfairness criteria. The results indicate significant dependencies $\left(\sqrt{ } \chi^{2}=0.50\right.$ and $\left.>0.2\right)$ between the rows and the columns in the correspondence matrix in support of the overall contention that features of capital gains tax have unfair characteristics. 


\section{Figure 2:}

Relationships between statements and unfairness criteria

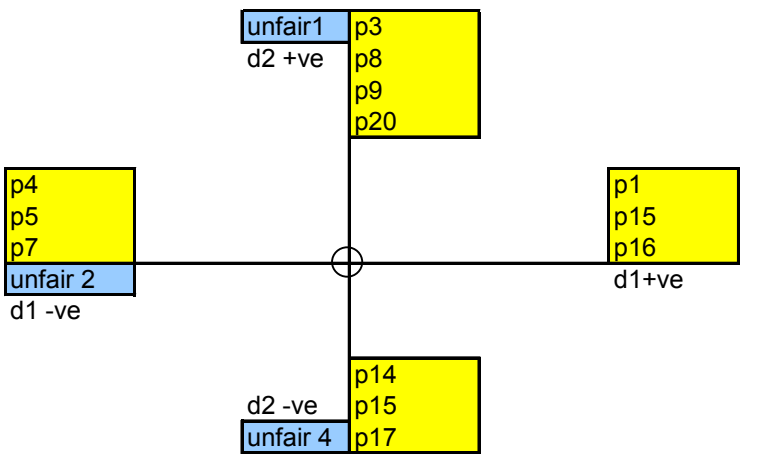

The results indicate that the two-dimensional bi-plot (axes) had a retention value of 90.22 per cent, which is highly explanatory. For the purpose of defining the axes of the correspondence plot, three unfairness criteria (columns) accounted for more than 90 per cent of the cumulative inertia (Bendixen, 1996). The allocation of these unfairness criteria to the respective axes is further illustrated in Figure 2. Due to the low inertia of unfairness characteristic 3 (0.076), it was not allocated an axis.

The influence of the paragraphs (statements) on the respective unfairness criteria (axes) is represented visually by the relative distance of a statement (plotted point) from the origin, as well as its position relative to a specific axis. The sign of a coordinate (plotted point), therefore, is not synonymous with its influence but rather its relationship with one of the unfairness criteria axes (Bendixen, 1996). The significance of the paragraphs (inertia), as well as their relationship with specific axes (Squared Correlation), is explained in Annexure B. To ensure that the findings are meaningful, while still retaining the explanatory power of the analysis, emphasis was placed on examining those plotted paragraphs (statements) which had the highest inertia and correlation coefficient contributions. To this end, a 0.3 correlation coefficient cut off was adopted in this paper.

Statements p20, p9, p8 and p3 are closely clustered and are positioned almost on the positive $y$-axis, thereby indicating a close correlation between these four statements and unfairness characteristic 1 , namely, that these statements promote double taxation. The respective correlation coefficients of the statements with the $y$-axis were $0.994,0.871,0.922$ and 0.601 respectively. All four statements, however, contributed less than 5 per cent towards the total inertia showing a relatively low level of influence with respect to their influence on promoting double taxation. Conversely, p14, p15 and p17 were clustered close to the negative $y$-axis suggesting a strong association between these statements and unfairness characteristic 4, namely, that the 'upfitment' of the poor is not promoted. All of these statements indicated a high level of correlation $(>0.5)$ between the statements and the negative y-axis. Statements 14 and 15, moreover, contribute 6.8 per cent and 12.6 per cent towards the total inertia, indicating a higher level of influence on unfairness criteria 4. Statement 17 only contributes 4 per cent towards the total inertia, indicating a lower level of influence.

Statements p1 and p16 indicated a high level of influence (0.098 and 0.066) with respect to the respondent's opinions with respect to CGT in a number of unfairness criteria. The results suggest these statements are significantly correlated with the positive $\mathrm{x}$ axis, suggesting that they influenced no particular unfairness criteria more than any other. Statement 15, which had the highest inertia (0.126), was less strongly correlated to this axis. On the examination of the original questionnaire it was evident by the scores that the respondents felt these statements could be attributed to more than one unfairness criteria. 
Finally, paragraphs p4, p5 and p7 were strongly correlated $(0.957,0.897,0.671)$ to the negative $y$-axis (Unfair 2), namely, that taxpayers did not contribute equally for stateprovided services. In particular, paragraph 4 had the highest inertia (0.193) of all the 20 statements with respect to its influence on unfairness characteristic 2. By contrast, paragraphs 5 and 7 had a much lower influence registering inertias of 0.037 and 0.04 respectively.

5

\section{Discussion}

This section further debates some concerns regarding the taxation of capital, the 'bunching' and lock-in problem, arguments surrounding vertical and horizontal equity and the issue of inflation adjustments. Finally, the anti-avoidance potential and administrative requirement of the Eighth Schedule is discussed with the notion of tax fairness as advanced by Smith

\section{Concerns regarding the taxation of capital}

The levying of a CGT charge on the death of a taxpayer (s3); the need for detailed supporting documentation to be retained (s8); steps to simplify the administrative burden associated with CGT (s9); and CGT, in general (s20), were strongly associated with the belief that, in substance, CGT is tantamount to a double tax.

The correlation of s3 with unfairness characteristic 1 is consistent with the views of Ricardo (1817), Stiglingh et al. (2011) and Moore and Silva (1995), all of whom raised concerns that the underlying CGT charge on death was a source of unfairness. The correlation between s8 and s9 also lends weight to the view that, while some steps have been taken to address the administrative load of CGT, these are largely inadequate and still result in a material indirect added charge for taxpayers, and a form of double tax (Wood, 2001; Meyerowitz et al. (d), 2001).

Prior academic work, however, also discussed the concern that CGT levied on the sale of equity instruments was a form of double tax (Stein, 2000; Stein, 2001). This was not highlighted by the analysis with Chart 3 showing no dominating correlation between s1 and unfairness characteristic 1. Annexure 1 also shows that the $\mathrm{CE}$ of $\mathrm{s} 1$ with the positive $\mathrm{y}$-axes is not significant $(<0.3)$ and provides only a low inertia ( 4.4 per cent) to that axis. While the Carter Commission (1966)(cited by Vlassenko, 2001), SARS (2000) and Manuel (2001) maintained that there was no evidence of double tax, and no inherent unfairness, this argument is not necessarily supported by the correspondence analysis. More specifically, the analysis did show a strong correlation between $\mathrm{s} 1$ and unfairness characteristic 4: that CGT may not promote the upliftment of the poor. In this way, while the correspondence analysis does not unconditionally confirm the double tax argument advanced by Stein (2000) and Stein (2001), the analysis does show a correlation with at least one of the unfairness characteristics and appears to refute the opinion of SARS (2000) and Manuel (2001) that CGT is free of innate unfairness.

\section{The 'bunching' and lock-in problem}

Dyl (1977), Auten and Cordes (1991), Moore and Kerepen (2001), Leonard et al. (2002) and Conda (2006) advanced that CGT yielded a lock-in effect and 'bunching problem' that resulted in an excessive charge for state services. This is largely consistent with the results of the Chart 3 which show a strong correlation between s4, s5 and s7 and the concern that taxpayers may not be paying a fair share for state services. This is contrary to the view that the lock-in effect could not be quantified and was limited to academic constructs (SARS, 2000; COSATU, 2001). Indeed, the relatively high total inertia contributed by s4, s5 and s7 (27 per cent in total) suggests the exact opposite: that tax experts regard this as a highly practical source of unfairness.

\section{Arguments surrounding vertical and horizontal equity}

The Katz Commission (1997), Meade (1978), Stiglitz (1976), SARS (2000) and COSATU (2001) maintained that CGT was a key means of entrenching equity in the South African tax system and for alleviating the tax burden on the poor. The correspondence analysis, 
however, appears to contradict these views. While the correspondence analysis did not reveal that the taxation of the wealthy (s10) and the need for equity (s11) were perceived as being unfair in themselves (s10 and s11 have low relative inertias), unfairness characteristic 4 has a relatively high inertia (23.2 per cent) and is strongly associated with several traits. In particular, consistent with Moore and Kerpen (2001), Arendse (2004) and Conda (2006), Chart 3 demonstrates a strong correlation with the fact that CGT imposes a tax burden on business start ups (s16\&17), empowerment deals (s16), recreational clubs (s15), and PBOs (s14) and an inability to promote the upliftment of the poor and disadvantaged. This is in contrast with the positive sentiment of COSATU (2001): that CGT is instrumental in wealth redistribution and poverty alleviation.

\section{Issue of inflation adjustments}

The absence of inflation adjustment was argued as resulting in an aggravation of the 'bunching' and lock-in problem (Staszczuk, 2001:10; Cordes, 2000:3). While s13 did not carry sufficient inertia for inclusion on Chart 3 , the point was, nevertheless, closely related with s6 and s7, dealing with 'bunching problem', as evidenced by the clustering of these points in the third quadrant in Chart 2. In this light, it appears that respondents did perceive the absence of inflation adjustment to be associated with the 'bunching problem'.

In spite of the absence of inflation adjustment having the ability to aggravate a 'bunching' or lock-in problem, the use of inflation indexing may prove 'horribly administratively complex' and too costly a solution (Krever, 2001; Ensor, 2000). This sentiment seems to find support in the correspondence analysis with s13 having a low inertia and relatively weak $C E$ with the $x$ and $y$ axis $(<0.3)$. It therefore appears that there is insufficient evidence to support the argument that the absence of inflation adjustment is a source of unfairness.

\section{The anti-avoidance potential and administrative requirement of the Eighth Schedule to the Act}

CGT's anti-avoidance potential was cited as a key example of the Sate entrenching ideals of fairness in the South African tax system (Moore \& Silva, 1995; SARS, 2000; COSATU, 2001; Wood, 2001; Cameron, 2001). In this regard, the correspondence analysis did not yield fully corroborating results. The traits dealing with anti-avoidance (s6, s7, s10 \& s19) were reasonably correlated with the dimensions of the plot in Chart 3. They did not, however, contribute high levels of inertia and were not regarded as key variables in the correspondence analysis. The analysis did not, therefore, initially identify a material correlation between the antiavoidance potential and the unfairness characteristics of CGT.

Critics, however, noted that CGT had only a limited anti-avoidance potential and that any gains in this regard were offset by high administrative costs while limiting much needed exemptions available to PBOs and recreational clubs (Wood, 2001; Vlassenko, 2001; South African Council of Churches, 2006). These counterarguments are supported indirectly by correspondence analysis with s15-s18 being strongly correlated with unfairness characteristics and having relatively high inertias. The perception that the administrative burden was a source of double tax was also noted in the analysis and was discussed in Section 6.4.1. In this way, the analysis seems to refute the argument that CGT's anti avoidance potential was a benefit that exceeded cost and entrenched fairness in the South African tax system.

\section{6}

\section{Conclusion}

The correspondence analysis revealed that there are potential sources of unfairness inherent in the Eighth Schedule. These include the possibility that that CGT gives rise to double tax, that it imposes a high burden on taxpayers' ability to bear the tax load and may undermine the upliftment of the poor. On the other hand, the relationship between CGT and the ability of taxpayers to bear a tax load was not regarded as a material one, with this characteristic contributing a relatively low inertia in the column space plot (Chart 1).

More specifically, the correspondence analysis confirmed the view that CGT may 
give rise to double tax. This was seen in the correlation between unfairness characteristic 1 and the administrative load associated with CGT (s8\&9) and the CGT charge arising on death (s3). The second aspect of Smith's (1776) definition was the ability of taxpayers to bear a tax burden. The 'bunching' and lockin problem (s4, s5 \&s7), poor anti-avoidance potential with high administrative load (s6, s7, s10 \& s19); and threat to business startups, BEE deals and PBOs (s14-s18) were confirmed by the correspondence analysis as being possible sources of unfairness in this context. In doing so, these traits challenged the upliftment of the previously disadvantaged.

Ultimately, the correspondence analysis has added to the debate surrounding the perceived fairness of CGT. Unfortunately, inherent limitations impair the reliability of the data. These include the fact that sample sizes are small and not sufficiently diverse to capture the opinion of the entire population of taxpayers. The analysis is based on the opinions of respondents, rather than on documented fact. The nature of the questions posed is such that the results may not easily be quantified in order to measure the probability of either the taxpayer or tax gatherer being correct. This is not regarded as a fundamental shortcoming as the interpretive nature of the research means that the intention was never to generalise findings or 'quantify' a result. Rather, the aim has been to inform perceptions and provide a platform for multiple perspectives.

These inherent limitations inevitably result in the reaching of a definitive conclusion with any reasonable level of assurance being highly improbable. Nevertheless, the results confirm the opinion of a number of sources in the literature and, to some extent, provide a degree of consensus while adding to the reliability of the views presented in the literature review.

\section{References}

AHRENS, T. \& CHAPMAN, C.S. 2006. Doing qualitative field research in management accounting: positioning data to contribute to theory. Accounting, Organizations and Society, 31(8):819-841.

ARENDSE. J. 2004. BEE and tax: should there be a common ground? Accountancy SA, October.

AUTEN, G. \& CORDES, P. 1991. Policy watch: cutting capital gains taxes. Journal of Economic Perspective, 5(1).

BENDIXEN, M. (1996) A practical guide to the use of correspondence analysis in marketing research, Marketing Research On-Line, 1: 16-38.

BLAXTER, L., HUGHES, C. \& TIGHT, M. 2003. How to research ( $2^{\text {nd }}$ ed.) Maidenhead Philadelphia: Open University Press.

BRENNAN, N. \& KELLY, J. 2007. A study of whistleblowing among trainee auditors. The British Accounting Review, 39:61-87.

BROOKS, P. 2001. Capital gains tax. Taxgram, May.

CAMERON, B. 2001. Capital gains tax. Personal Finance, October. Available at: http://www.persfin.co.za/html/persfin/cgt/page1.php (accessed 2006-03-15).

COETZEE, K. 1998. Problems with equity in taxation with special emphasis on the South African situation, in K.H. Kleynhans (ed.) South African Accounting Association Biennial Conference, 9 July 1998, Johannesburg. Johannesburg: South African Accounting Association.

COMMERCIAL ORGANISATION OF SOUTH AFRICAN TRADE UNIONS (COSATU). 2001. Capital gains tax: presentation to the portfolio committee on finance, January. Available at: http://www.cosatu.org.za/ docs/1999/progtax.htm (accessed 2006-03-10).

CONDA, C. 2006. The best cap-gains tax rate is zero. Available at: http://www.freedomworks.org/ informed/issues_template.php?issue_id=2524 (accessed 2006-02-10).

CORDES, J. 2000. Capital gains tax. Available at: http://www.econlib.org/library/ENC/ CapitalGainsTax.html (accessed 2006-02-10).

CRESWELL, J.W. 2009. Research design: qualitative, quantitative, and mixed methods approaches $\left(3^{\mathrm{rd}} \mathrm{ed}\right.$.) London: Sage Publications.

CROOME, B. 2007. Timing of CGT valuations: submissions to SARS. Tax Planning, 21(1). 
DYL, E. 1977. Capital gains tax and year end stock market behaviour. The Journal of Finance, 32(1). ENSOR, L. 2001. More tax concessions for the middle class. Business Day, March 15.

FARRAR, J. 2011. Tax fairness in Canadian government budgets: How fair is 'fair'? Critical Perspectives on Accounting, 22:365-375.

FRIEDLAND, R. 2001. The noose is tightening, don't try to be too clever. Financial Mail, August 11. GROVES, H. \& CURRAN, J. 1974. Tax philosophers (1974 ed.) Wisconsin: University of Wisconsin Press. KATZ COMMISSION. 1995. Third interim report of the commission of inquiry into certain aspects of the tax structure of South Africa. Pretoria: Government Printer.

KREVER, R. 2001. A capital gains tax for South Africa. Presentation to the Portfolio Committee on Finance and the Select Committee on Finance. Available at: http://www.ftomasek.com/RickKreverDraft.html (accessed 2007-11-06).

LEEDY, P.D. \& ORMROD, J.E. 2001. Practical research: planning and design. Upper Saddle River, NJ: Merrill/Prentice Hall.

LEONARD, E., RANDOLPH, B. \& RANDOLPH, W. 2002. Measuring permanent responses to capital-gains tax: changes in panel data, American Economic Review 84(4). Available at: http://www.jstor.org/cgibin/jstor/printage/00028282/di976326/97p0149b/0.pdf?backcontent=page\&dowhat=Acrobat\&config=jstor\&u serID=928d0fdf@wits.ac.za/01cc00332800501bd0bec\&0.pdf (accessed 2007-06-01).

MANUEL, T. 2001. Why capital gains should be taxed, Financial Mail, February 9.

MEADE, J. 1978. The structure and reform of direct taxation, The Institute for Fiscal Studies. London: George Allan \& Unwin.

MERCHANT, K.A. 2008. Why interdisciplinary accounting research tends not to impact most North American academic accountants. Critical Perspectives on Accounting, 19:901-908.

MEYEROWITZ, D, EMSILE, T. \& DAVIS, D. 2001a. Capital gains tax, The Taxpayer, 50(4).

MEYEROWITZ, D.. EMSILE, T. \& DAVIS, D. 2001b. Capital gains, The Taxpayer, 50(5).

MEYEROWITZ, D., EMSILE, T. \& DAVIS, D. 2001c. Capital gains tax implications arising from recent events in New York, The Taxpayer, 50(9).

MEYEROWITZ, D., EMSILE, T. \& DAVIS, D. 2001d. Capital gains tax (Eighth Schedule to the Income Tax Act) - valuation of assets, The Taxpayer, 50(10).

MONTESQUIEU, B. 1784. The spirit of the law. London: G. Bell \& Sons, Ltd. 1914. Available at: $\mathrm{http} / / / \mathrm{www}$. constitution.org/cm/sol.htm (accessed 2006-11-11).

MOORE, S. \& KERPEN, P. 2001. A capital gains tax cut: the key to economic recovery. Institute for Policy Innovation, Report No. 164. Available at: http://www.ipi.org/ipi/IPIPublications.nsf/ PublicationLookupFullText/EC18ED9B8007A06486256AE2002BA80D (accessed 2007-10-12).

MOORE, S. \& SILVA, J. 1995. The ABC's of capital gains tax, Cato Institute: Policy Analysis No. 242, October. Available at: https://cato.org/pub_display.php?pub_id=1101\&print=Y\&full=1 (accessed 2007-07-09).

MUSGRAVE, R. 1968. The Carter Commission Report, The Canadian Journal of Economics, 1(1) Available at: http://limks.jstor.org/sici?sici=0008-4085\%28196802\%291\%3A1\%3C159\%3ATCCR\%3E2.0.CO\% 3B2-U (accessed 2007-11-10).

NEUENDORF, K.A. 2002. The content analysis guide book. Thousand Oaks, CA: Sage Publications.

O'DWYER, B., OWEN, D. \& UNERMAN, J. 2011. Seeking legitimacy for new assurance forms: the case of assurance on sustainability reporting. Accounting, Organizations and Society, 36:31-52.

OLIVIER, L. 2007. Determining a taxable capital gain or assessed capital loss: some problems, Meditari Accountancy Research, 15(1):35-50.

PARKER, L.D. \& ROFFEY, B.H. 1997. Methodological themes: back to the drawing board - revisiting grounded theory and the everyday accountant's and manager's reality, Accounting, Auditing and Accountability Journal, 10(2):212-247.

PRICEWATERHOUSECOOPERS. 2000. CGT: no pain, no gain $\left(5^{\text {th }} \mathrm{ed}\right.$.) Johannesburg: PricewaterhouseCoopers.

RICARDO, D. 1817. The principles of political economy and taxation. London: John Murry, 1984. Available at: http://www.econlib.org/LIBRARY/Ricardo/ricP.html (accessed 2007-07-01). 
ROBERTS, S. 2006. Capital gains tax: advantages \& disadvantages of capital gains tax cut. India Finance and Investment Guide, July. Available at: http://finance.indiamart.com/taxation/advantages_ disadvantages_capitalgains.html (accessed 2006-11-11).

SMITH, A. 1776. An inquiry into the nature and causes of the wealth of nations.

SOUTH AFRICAN COUNCIL OF CHURCHES. 2006. Submission to the Portfolio Committee on Finance. Available at: http://www.sacc-ct.org.za/rlab2006.html (accessed 2007-05-31).

SOUTH ARFICAN REVENUE SERVICE. 2010. Budget Speech (2010). Available at: http://www.treasuary.gov.za (accessed 2010-09-10).

SOUTH AFRICAN REVENUE SERVICES. 2000. Guide to capital gains tax. Available at: http://www.treasuary.gov.za/documents/budget/2000/cgt/cgt.pdf (accessed 2006-11-11).

STASZCZUK, O. 2001. Capital gains tax: the pros and cons. The Free Market Foundation, Monograph No. 28.

STEIN, M. 2000. Capital gains tax. Income Tax Reporter, 39(3).

STEYN, G. 2001. SARS stands firm on capital gains tax, Business Day, 11 May.

STIGLINGH, M., KOEKEMOER, A.D, WILCOCKS, J. 2011. SILKE: South African income tax 2011. LexisNexis: South Africa.

STIGLITZ, J.E. 1976. Simple formulae for optimal income taxation and the measurement of inequality. Stanford, CA: Institute for Mathematical Studies in the Social Sciences, Stanford University.

THOMAS, S. 2001. No place left to hide, Financial Mail, August 9.

VIVIAN, R. 2006. Equality and personal income tax: the classical economist and the Katz Commission. South African Journal of Economics, 74(1).

VLASSENKO, I. 2001. Evaluation of the efficiency and fairness of the British, French and Swedish property tax systems. Property Management, 15(5). Available at: http://www.emeraldinsight.com.innopac.wits.ac.za/ Insight/viewPDF.jsp?Filename=html/Output/Published/EmeraldFullTextArticle/Pdf/1130190502.pdf (accessed 2007-11-13).

VOSTER, D. 2000. Capital gains tax: a discredited tax. Tax planning, 14(6).

WOOD, S. 2001. Brace for the blade. The Financial Mail, August.

\section{Personal correspondence}

- STACEY, A. (Anthony.Stacey@wits.ac.za) 28 November 2007, RE: Correspondence analysis: results, emailed to W. Maroun (Warren.Maroun@wits.ac.za) (Dr A. Stacey is a BSc (Electrical Engineering) graduate of the University of Cape Town with an MBA and PhD from the University of the Witwatersrand. He currently lectures at the University of the Witwatersrand Business School.)

- HONIBALL, M. (Michael.Honiball@kpmg.co.za), 16 November 2007, RE: Tax avoidance, emailed to W. Maroun (Warren.Maroun@wits.ac.za) (Mr Honniball was a Tax Partner in the employ of KPMG at the time of the research.) 